\title{
Some Ecological Factors Influencing Egg Hatching, Incubation Period, Food Consumption and Aestivation of Monacha cartusiana Snails Under Laboratory Conditions Samah M. Abdel-Kader and M. H. E. Lokma. Plant Protection Research Institute, ARC, Dokki, Giza, Egypt.
}

\section{ABSTRACT}

This study was conducted on the land snail Monacha cartusiana to determine the influence of four different degrees of temperature $\left(18,20,22\right.$ and $\left.24{ }^{\circ} \mathrm{C}\right)$ treated with four levels of soil moisture $(25,50,75$ and $100 \%$ field capacity) on egg hatching and developmental period and to define the activity of snails during aestivation and food consumption under the effect of seven temperature degree ranges $\left(5,10,15,20,25,30\right.$ and $\left.35^{\circ} \mathrm{C}\right)$ under laboratory conditions. The present data revealed that the optimum temperature $\left(22^{\circ} \mathrm{C}\right)$ for the highest percent of egg hatching was $(78$ and $76 \%)$ treated with 75 and $100 \%$ of soil field capacity and the shortest incubation and hatching period were 4.6 and 0.8 days at $24^{\circ} \mathrm{C}$ with $75 \%$ soil moisture and at $20^{\circ} \mathrm{C}$ with $50 \%$ soil moisture, respectively. Food intake by M. cartusiana on cabbage leaves was directly related to temperature and the land snail sizes. Feeding was maximal at 20 and $35^{\circ} \mathrm{C}$ for juveniles $(8-9,10-11 \mathrm{~mm})$ and at 5 and $35{ }^{\circ} \mathrm{C}$ for all sizes of adults. All juveniles sizes showed higher food intake rate (general mean,31.14mg) than the adult sizes (general mean,30.20mg), as it increased by increasing only the shell size of all juveniles indicated by the general mean which could be arranged in an ascending order as follows, 29.03, 31.04 and $33.37 \mathrm{mg}$ for the size of (8-9), (9-10) and (10-11 mm), respectively, during three days. When the aestivated snails were exposed to serial levels of temperature degrees (starting from 10 to $40^{\circ} \mathrm{C}, 15$ to $40^{\circ} \mathrm{C}, 20$ to $40^{\circ} \mathrm{C}, 25$ to $40{ }^{\circ} \mathrm{C}$ and 30 to $\left.40^{\circ} \mathrm{C}\right)$, were more active $(19.2,50,17.2$, and $3.6 \%)$ at temperature $25^{\circ} \mathrm{C}$ and became less active with increasing temperature $(0.4,6.4,7.6,5.6$ and $4 \%)$ at $40{ }^{\circ} \mathrm{C}$. By the end of the experiment, all the aestivated snails become epiphragmed and only died when exposed suddenly to a lower temperature, while it still alive when exposed to higher temperature.

Keywords: Monacha cartusiana, temperature, egg hatching, developmental period, food consumption, emergence from aestivation.

\section{INTRODUCTION}

The Gastropoda is the only class of mollusks which have successfully invaded land. They are one of the most diverse groups of animals, both in shape and habits. Among gastropods, land snails (subclass: Pulmonata) are harmful pests to many crops worldwide (Godan, 1983). Singled out-that, the glossy clover snail, M. cartusiana (Muller) which is the major species found in a wide range of crops in most localities of Egypt specially at Sharkia Governorate. Individuals of this species cause a heavy damages to economically important crops (Nakhla et al., 1995; ElMassry, 1997; Mahrous et al., 2006; Lokma, 2007; Abdel-Aal, 2007 and Shahawy et al., 2008).

These snails have active dispersal capabilities which enable it to successfully expand its range to new areas, its success may be due to its environmental tolerances, high fecundity, and adaptability to the new habitats (El-Okda,1981).Temperature, the relative humidity, photoperiod, food supply and habitat characteristics are considered the most important factors influencing the occurrence/survival of land snails (Panigrahi and Raut, 1994; Millar and Waite, 2002; Mahrous et al.,2002; Metwally, et al., 2002; Martin and Sommer 2004 and Ramzy, 2009). Temperature and humidity are the primary factors determining snail activity (Cook, 2001). Adequate knowledge of biology and ecology of pests should be acquired before application of management purpose to control these harmful animals.

The objectives of this research were to determine egg hatching, incubation period, hatching period and food consumption of $M$. cartusiana over-narrower ranges of temperature degrees and soil moisture under laboratory conditions. Moreover, effect of wide ranges of temperature degrees on aestivation of M. cartusiana was studied also.

\section{MATERIALS AND METHODS}

1- Collection of snails:

The required individuals of the terrestrial snail, $M$. cartusiana were collected in the early morning from heavily infested field cultivated with Egyptian clover (Trifolium alexandrinum), at El-Nakhas locality, Zagazig district, Sharkia Governorate during activity season in March 2015. The collected snails were classified to seven groups each of size class interval of one $\mathrm{mm}$ according to shell diameter using a vernier caliper accurate to $0.02 \mathrm{~mm}$. Snails with shell diameter $8,9,10$ and 11 were considered as juveniles, while those of shell diameter $12,13,14,15$ and $16 \mathrm{~mm}$ were classified as adults based on the presence of maturation lip around the shell opening as the main criterion to recognize maturity. Snails of each group were placed in rearing containers $(50 \times 30 \times 30 \mathrm{~cm})$ and fed daily on fresh cabbage leaves for at least 10 days before experiment to acclimatize under laboratory conditions.

2- The effect of different temperatures degrees and soil moisture levels on egg hatching, incubation and hatching period of $M$. cartusiana :

To study hatching period (time elapsed between the date which the first egg hatched and the date which the last egg hatched) for M. cartusiana, newly deposited egg clutches were removed carefully from the laboratory culture and placed separately in small plastic pots of $10 \mathrm{~cm}$ diameter filled with sterilized clay soil to a depth of about $5 \mathrm{~cm}$. Soil moistures was adjusted to 25 , 50,75 and $100 \%$ of field capacity. The pots were placed in incubators at four temperature degrees 18, 20, 22 and $24{ }^{0} \mathrm{C}$. Five replicates were used for each treatment. Egg masses were examined daily and the newly hatched juveniles were recorded and removed to avoid egg cannibalism (Baur, 1990). Examination was continued until the last eggs were hatched. Data were statistically analyzed using $\mathrm{F}$ test and least significant difference 
(L.S.D.) were calculated using MUTST program version 4 (1986).

\section{3- The effect of different temperatures on the food} consumption of snails:

The effects of temperature on the food intake of the terrestrial snail, $M$. cartusiana were investigated using three size groups for juvenile ranged from 8 $11 \mathrm{~mm}$ and four size groups for adult ranged from 12-16 $\mathrm{mm}$ in shell diameter (SD). Five snails of each size group were assigned into plastic pot $(10 \mathrm{~cm}$ diameter) filled with clay soil. All of pots were exposed to a set of seven different temperature degrees $(5,10,15,20,25$, 30 and $35{ }^{\circ} \mathrm{C}$ ) using refrigerator incubators. Two fresh cabbage discs with diameter $2 \mathrm{~cm}$ were weighed and offered to the snails daily, for three successive days. After 24 hours, the old food residues were weighed and replaced by fresh weighed food for each pot. This procedure was adopted for all snails groups concurrently and replicated five times for each temperature degree. The feeding activity was observed and the consumed amount of food was measured daily according to (Waldbaner, 1964). The obtained data were subjected to statistical analysis using least significant difference (L.S.D) as comparative mean.

4- The effect of temperatures on the activity of snails during aestivation:

This experiment was undertaken during August 2015 , where the range of the soil surface temperature ranged from 30 to $35^{\circ} \mathrm{C}$ and the epiphragm adult snails were found near damp habitats either under grasses or tunnels of irrigation canals and under the lowered portion of the tree trunks. A series of five experiments was conducted to determine the effect of exposure to gradual increase in temperature on aestivation. Five groups of ten epiphragm adult snails, of $M$. cartusiana (12-13mm SD) were introduced directly into pots (10 $\mathrm{cm}$ diameter) filled with dry clay soil to depth about 5 $\mathrm{cm}$. All groups of epiphragm adult snails were subjected directly to different levels of temperature degrees without acclimatization, starting from (10- 15- 20- 2530- $\left.35-40{ }^{0} \mathrm{C}\right),\left(15-20-25-30-35-40{ }^{\circ} \mathrm{C}\right),(20-25-30$ $\left.35-40{ }^{\circ} \mathrm{C}\right),\left(25-30-35-40{ }^{\circ} \mathrm{C}\right)$ and $\left(30-35-40{ }^{\circ} \mathrm{C}\right)$ each per 5 days with added a new epiphragm adult snails for each test group of temperature degrees - over a period of 125 days. For each test temperature degree, five replicates were used. Pots were checked daily, at the end of each experiment; the percentage of non epiphragm snails was recorded and is taken as an indication of the activity. During the entire experiment, relative humidity was at or nearly at $(65-70 \%)$, with free bottled water placed at the bottom of incubator.

\section{RESULTS AND DISCUSSION}

1-The effect of different temperature degrees and soil moisture levels on egg hatching, incubation and hatching period of $M$. cartusiana:

The influence of four temperature degrees $\left(18,20,22\right.$, and $\left.24^{\circ} \mathrm{C}\right)$ and four soil moisture grades $(25$, 50,75 and $100 \%$ of field capacity) on egg hatching, incubation and hatching period of $M$. cartusiana snails were studies under laboratory conditions. Data in Table (1) indicated that at soil moisture level $25 \%$ none of the tested eggs were hatched under all tested temperature degrees $\left(18,20,22\right.$, and $\left.24^{\circ} \mathrm{C}\right)$. The hatching percentage started to increase gradually from 26 to $34 \%$ and from 10 to $42 \%$ as the soil moisture increased to $50 \%$ and $70 \%$ at $18^{\circ} \mathrm{C}$ and $20^{\circ} \mathrm{C}$, respectively till reaching its maximum values averaging 78 and $76 \%$ at temperature of $22{ }^{\circ} \mathrm{C}$ with $75 \%$ and $100 \%$ of soil field capacity. As the temperature increased to $24{ }^{0} \mathrm{C}$, the average percentage of hatchability was decreased to 28 and $60 \%$, at 75 and $100 \%$ of field capacity, respectively. So, the optimal conditions for egg hatching are $22^{\circ} \mathrm{C}$ and when the soil moisture reached $75-100 \%$ of field capacity. On the other hand, under the highest levels of both temperature $\left(24^{0} \mathrm{C}\right)$ and soil moisture (75 and $100 \%$ of field capacity) the incubation period was shorter (4.6 and 8.2 days) than the values that obtained at lowest level of $18^{\circ} \mathrm{C}(12.2,10.6$ and 17.4 days), at 50, 75 and $100 \%$ of field capacity, respectively. In addition the shortest hatching period was recorded ( 0.8 days), at $20{ }^{0} \mathrm{C}$ with $50 \%$ of field capacity, and was longer $(5.6$ days) at lower temperature level $18{ }^{\circ} \mathrm{C}$ and $100 \%$ of field capacity Table (2). On the other hand,

Table 1. Effect of different temperatures and soil moisture levels on egg hatching of $M$. cartusiana under laboratory conditions.

\begin{tabular}{lccccc}
\hline & \multicolumn{5}{c}{ Eggs hatching (\%) } \\
\cline { 2 - 6 }$\left({ }^{0} \mathrm{C}\right)$ & $\mathbf{5}$ Soil moisture levels \\
\cline { 2 - 6 } & $\mathbf{5 0}$ & $\mathbf{7 5}$ & $\mathbf{1 0 0}$ & $\begin{array}{c}\text { L.S.D } \\
(\mathbf{0 . 0 5})\end{array}$ & $\begin{array}{c}\text { General } \\
\text { mean }\end{array}$ \\
\hline 18 & $26 \pm 14.69$ & $34 \pm 17.20$ & $70 \pm 9.48$ & N.S & 43.33 \\
20 & $10 \pm 100$ & $42 \pm 15.62$ & $76 \pm 12.49$ & $39.779^{*}$ & 42.66 \\
22 & $00 \pm 00$ & $78 \pm 13.54$ & $76 \pm 10.29$ & $30.295^{* * *}$ & 51.33 \\
24 & $00 \pm 00$ & $28 \pm 19.59$ & $60 \pm 17.02$ & $46.186^{*}$ & 29.33 \\
General & $9.00^{\mathrm{c}}$ & $45.50^{\mathrm{b}}$ & $70.50^{\mathrm{a}}$ & & 41.66 \\
mean & \multicolumn{5}{c}{$22.894 * * *$} \\
L.S.D $(0.05)$ & \multicolumn{5}{c}{ N.S } \\
\hline
\end{tabular}

* Different letters indicated significant effect at $\mathbf{P}<0.05$

* Significant $(\mathrm{P}<0.05)^{* * *}$ highly significant $(\mathrm{P}<0.01)$.

Results of ANOVA tested (L.S.D.) clearly revealed that a highly significant difference $(\mathrm{P}<0.01)=$ $22.894 * * *$ in egg hatching was found at all the different temperature degrees within all levels of different soil moisture levels Table (1). In Table (2) there was a variance between the different temperature degrees at all levels of different soil moisture ranged from significant to insignificant. At temperature $22^{\circ} \mathrm{C}$ showed highly significant difference for incubation period $\left(0.616^{* * *}\right)$ and hatching period $\left(0.941^{* * *}\right)$ of $M$. cartusiana snails at all different soil moisture levels. This however was insignificant with the temperature $20^{\circ} \mathrm{C}$. The interaction between all the different temperature degrees and all the different soil moisture levels is also significant $\left(8.528^{*}\right)$ and (1.598**). Therefore, temperature and soil moisture are significant factors affecting snails vital activities. 
Table 2. Impact of temperatures and soil moisture contents on incubation and hatching period of $M$. cartusiana under laboratory conditions.

\begin{tabular}{lcccccccccc}
\hline $\begin{array}{l}\text { Temperature } \\
\text { (c) }\end{array}$ & \multicolumn{4}{c}{ Incubation period(days) } & \multicolumn{4}{c}{ Hatching period(days) } \\
\cline { 2 - 12 } & $\mathbf{5 0}$ & $\mathbf{7 5}$ & $\mathbf{1 0 0}$ & L.S.D(0.05) & G. mean & $\mathbf{5 0}$ & $\mathbf{7 5}$ & $\mathbf{1 0 0}$ & L.S.D(0.05) & G. mean \\
\hline 18 & $12.2 \pm 50$ & $10.6 \pm 4.42$ & $17.4 \pm 0.50$ & N.S & 13.40 & $1.0 \pm 0.54$ & $2.4 \pm 1.02$ & $5.6 \pm 0.50$ & $2.264^{* *}$ & 3.00 \\
20 & $8.8 \pm .80$ & $11.6 \pm 2.97$ & $12.4 \pm 0.24$ & N.S & 10.93 & $0.8 \pm 0.80$ & $3.6 \pm 1.46$ & $3 \pm 0.44$ & N.S & 2.46 \\
22 & $00 \pm 00$ & $11.6 \pm 0.24$ & $11.6 \pm 0.24$ & $0.616^{* * *}$ & 7.73 & $00 \pm 00$ & $2.2 \pm 0.48$ & $1.8 \pm 0.200$ & $0.941^{* * *}$ & 1.33 \\
24 & $00 \pm 00$ & $4.6 \pm 2.82$ & $8.2 \pm 2.05$ & $6.213^{*}$ & 4.26 & $00 \pm 00$ & $0.2 \pm 0.73$ & $2.2 \pm 0.58$ & $1.668^{* *}$ & 0.80 \\
G. mean & $5.20^{\mathrm{a}}$ & $9.60^{\mathrm{a}}$ & $12.40^{\mathrm{a}}$ & N.S & 9.06 & $0.45^{\mathrm{ab}}$ & $2.10^{\mathrm{ab}}$ & $3.15^{\mathrm{a}}$ & N.S & 1.90 \\
L.S.D. & & & $8.528^{*}$ & & N.S & & & $1.598^{* *}$ & N.S \\
\hline
\end{tabular}

* Different letters indicated significant difference at $\mathrm{P}<0.05$.

* Significant $(\mathrm{P}<0.05) * * *$ highly significant $(\mathrm{P}<0.01)$.

The best temperature for egg hatching in this study was $22{ }^{0} \mathrm{C}$ with $75-100 \%$ of field capacity. This conclusion is in close agreement with those reported by many authors (Mohamed, 1999, Al-Akra, 2001 and Mohamed,Ghada, 2004) who found that $20^{\circ} \mathrm{C}$ gave the best hatching rate for Eobania vermiculata, $M$. cartusiana and M. obstructa. Also this finding is very similar to results reported by Baur and Baur, (1993) who reported that the hatching optima for Cepaea nemoralis were at 22 and $25^{\circ} \mathrm{C}$. The finding indicated that $20^{\circ} \mathrm{C}$ temperature and soil moisture $50 \%$ of this experiment accelerate development rate and reduced the duration of the developmental stages is similar to findings of Clave, (1989) who reported that the length of incubation period for Helix aspersa was negatively correlated with temperature.

2-The effect of temperatures on food consumption of juvenile and adult stages of $M$. cartusiana:

Data concerning the daily food consumption of fresh cabbage leaves as a food by three sizes of juvenile and four sizes of adults of the land snail, M. cartusiana during three successive days of experimental period are presented in Table (3). As the temperature increased from 5 to $30{ }^{0} \mathrm{C}$, there was no stability in the feeding rates for all sizes of both juvenile and adult snails.

The daily values were higher $(41.46 \mathrm{mg})$ for juvenile $(8-9 \mathrm{~mm})$ at $20{ }^{0} \mathrm{C}$ than that obtained $(35.86$ and $37 \mathrm{mg}$ ) by juveniles $(9-10$ and $10-11 \mathrm{~mm})$ at 10 and $15^{\circ} \mathrm{C}$, respectively. However the lower values were recorded $(14.86,15.90$ and $21.93 \mathrm{mg}$ ) for juveniles of 89, $10-11 \mathrm{~mm}$ at $30^{\circ} \mathrm{C}$ and $9-10 \mathrm{~mm}$ at $20{ }^{0} \mathrm{C}$, respectively. At temperature $35{ }^{0} \mathrm{C}$, the feeding rates reached a maximum values (80.80) for juvenile (10-
$11 \mathrm{~mm})$ followed by relatively lower values $(37.10 \mathrm{mg})$ for both juveniles sizes of 8-9 and 9-10 mm. Regarding adult snails, it was noticed that at low temperature $5^{\circ} \mathrm{C}$ a remarkable increase in the consumption rate was attained $(32.93,52.13,41.46$ and $45.40 \mathrm{mg}$ ) for adult sizes $12-13,13-14,14-15$ and $15-16 \mathrm{~mm}$, respectively and these values increased till reached to the maximum values by the end of experiment at high temperature $\left(35^{\circ} \mathrm{C}\right)$, became $44.66,52.53,60.06$ and 61.10 for adult snails $12-13,13-14,14-15$ and 15-16 mm, respectively.

It can be noticed that the rate of food intake by all sizes of juveniles increased with increasing the shell size diameter. This was indicated by the general mean of food consumption which could be arranged in ascending order as follow, 29.03, 31.04 and $33.37 \mathrm{mg}$ for juvenile size (8-9, 9-10 and 10-11 mm), respectively, while the size groups of adult snails (12$13,13-14,14-15$ and $15-16 \mathrm{~mm}$ ) showed unstable in feeding rate $(25.62,33.07,30.33$ and $31.70 \mathrm{mg})$, respectively. Also the obtained data declared that the total mean food intake by all sizes of juveniles snails was fairly higher $(31.14 \mathrm{mg})$ than intake by all sizes of adults snails $(30.18 \mathrm{mg})$. As corroboration, all of individuals exhibited maximal feeding activity with the increasing the thermal conditions to overcome dehydration, to reach maturity and to enter a dormant state (aestivation). Moreover, for all size groups tested we found no significant difference $\mathrm{P}<0.05$ in daily ration among the gradually exposure of different temperature degree within all size classes of adult and juvenile snails through the period of experiment (3 days).

Table 3. Effect of different temperature degrees on food consumption of juveniles and adults of $M$. cartusiana under laboratory conditions.

\begin{tabular}{|c|c|c|c|c|c|c|c|c|c|}
\hline \multirow{2}{*}{$\begin{array}{l}\text { Shell } \\
\text { diameter(mm) }\end{array}$} & \multicolumn{7}{|c|}{ Temperature degree $\left({ }^{0} \mathrm{C}\right)$} & \multirow{2}{*}{$\begin{array}{l}\text { L.S.D } \\
(0.05)\end{array}$} & \multirow{2}{*}{$\begin{array}{c}\text { General } \\
\text { mean }\end{array}$} \\
\hline & 5 & 10 & 15 & 20 & 25 & 30 & 35 & & \\
\hline$\stackrel{8}{9} \quad(8-9)$ & 37.53 & 30.73 & 24.60 & 41.46 & 16.93 & 14.86 & 37.10 & & 29.03 \\
\hline$(9-10)$ & 34.40 & 35.86 & 34.20 & 21.93 & 30.86 & 22.93 & 37.10 & & 31.04 \\
\hline$(10-11)$ & 20.93 & 23.66 & 37.00 & 30.93 & 24.40 & 15.90 & 80.80 & & 33.37 \\
\hline $\begin{array}{l}\text { General mean } \\
\text { L.S.D }(0.05)\end{array}$ & 30.95 & 30.08 & 31.93 & $\begin{array}{l}31.44 \\
\text { N.S }\end{array}$ & 24.06 & 17.89 & 51.66 & & 31.14 \\
\hline$(12-13)$ & 32.93 & 22.93 & 17.86 & 25.80 & 25.60 & 9.60 & 44.66 & ח & 25.62 \\
\hline$(13-14)$ & 52.13 & 32.66 & 25.46 & 33.06 & 16.93 & 18.73 & 52.53 & & 33.07 \\
\hline$(14-15)$ & 41.46 & 19.40 & 25.13 & 39.06 & 14.73 & 12.53 & 60.06 & & 30.33 \\
\hline$(15-16)$ & 45.40 & 25.93 & 20.46 & 18.73 & 35.33 & 15.06 & 61.10 & & 31.70 \\
\hline $\begin{array}{l}\text { General mean } \\
\text { L.S.D }(0.05)\end{array}$ & 42.98 & 25.23 & 22.22 & $\begin{array}{l}29.16 \\
\text { N.S }\end{array}$ & 23.14 & 13.98 & 54.58 & & 30.18 \\
\hline
\end{tabular}


The change of temperature have a profound effect on the ability of these snails to acquire their food from the environment. High consumption rates were achieved at $10,15,20$ and $35{ }^{\circ} \mathrm{C}$ for certain sizes of juvenile and at 5 and $35^{\circ} \mathrm{C}$ for all sizes of adult snails. This result is in agreement partially with Osunkeye, et al.( 2006) who assured that ambient temperature (29.4 ${ }^{0} \mathrm{C}$ ) and moistening the soil with $65 \mathrm{ml}$ of water on daily basis increase feed intake and reduced the mortality rate of the giant African land snails, thereby increasing their survivability. Also Abed,( 2017) found that the highest food consumption was occurred at 25 and $30^{\circ} \mathrm{C}$ for juveniles of $M$. cartusiana and Eobania vermiculata, respectively and at $15^{\circ} \mathrm{C}$ for adult stages of both snail species. While this finding is in contrary with Lokma, (2013) who found that the maximum food intake rate of cabbage for both juveniles and adults of $M$. cartusiana, occurred at $30^{\circ} \mathrm{C}$ after 7 days

The finding that feeding activities of juvenile individuals were higher than adult individuals, as it increased with increasing their shell size, in response to increasing temperature over a range of 5 to $35^{\circ} \mathrm{C}$, were similar to those previously found by Lokma, (2013) who reported that juveniles of $M$. cartusiana registered the higher food consumption rate of cabbage $(31.85 \mathrm{mg}$ ) than adult snails $(23.14 \mathrm{mg})$ at $10^{\circ} \mathrm{C}$ during 7 days.

Generally, it could be concluded that the food consumption rates were dependent on the land snails size and temperature degrees.

3-The effect of temperatures on the emergence $M$. cartusiana from aestivation:

Percentage of emerged adult snails from aestivation due to exposure to gradual increase of temperature levels $\left(10-15-20-25-30-35-40{ }^{\circ} \mathrm{C}\right),(15-$ $\left.20-25-30-35-40{ }^{0} \mathrm{C}\right),\left(20-25-30-35-40{ }^{0} \mathrm{C}\right),(25-$ 30- 35- $\left.40{ }^{0} \mathrm{C}\right)$ and $\left(30-35-40{ }^{\circ} \mathrm{C}\right)$ after 5days is shown in Table (4:groups 1,2,3,4,5) .Data in all the first three groups levels, (groups 1,2,3) starting from10-1520- 25- 30- 35- $40{ }^{0} \mathrm{C}$ to $15-20-25-30-35-40{ }^{\circ} \mathrm{C}$ and 20- 25- 30- 35- $40^{\circ} \mathrm{C}$ ) indicated that the exposure to $25{ }^{0} \mathrm{C}$ showed the highest rate of emerged adult snails (19.2, 50 and17.2\%) while those at the highest level (40 $\left.{ }^{0} \mathrm{C}\right)$ showed the lowest rate of non-epiphragm adult snails $(0.4,6.4$ and $7.6 \%)$. Although the initiation with low temperature degrees favored the activity of the snails, the snails withdrawn into their shell and closed on itself with epiphragm and died by the end of the experiment, this may be due to that the aestivated snails are unable to accommodate metabolically when exposed suddenly to lower temperature levels (can not avoid low heat shock). However, in natural situations, temperatures usually change gradually enough to adjust its metabolic rates in an orderly manner (Ackefors, et al.1994).

On the other hand, non-epiphragm adult snails percentage (active snails) were greatly affected by increasing the levels of temperature degrees which represented in the four and five group, (25-30- 35 and $40^{\circ} \mathrm{C}$ ) and (30- 35and $\left.40^{\circ} \mathrm{C}\right)$. Reduced activities was recorded at all the temperature degrees whereas the average percentage rate did not exceed of $5.6 \%$ at $40^{\circ} \mathrm{C}$ (group4)and at $30^{\circ} \mathrm{C}$ (group5) and declined to a minimum rate of $2 \%$ at 30 and $35^{\circ} \mathrm{C}$ (group 4 ) and $4 \%$ at 35 and $40^{\circ} \mathrm{C}$ (group 5). It was noteworthy that although the initiated temperature degrees slightly elevated outside the optimum ranges of snails activation, also all snails for both (4) and (5) groups closed on itself with epiphragm but remaining alive this mean that aestivated snails has capability to regulate their internal temperature as increasing the risk of dehydration with high temperature levels by tendency to ceased its activity and enter in the dormant state (aestivation) (Akinnusi, 2014) to overcome high temperature and dehydration through numerous behavioral, biochemical and physiological adaptations which support long term aestivation (Storey, 2002, Kingsolver and Huey 2008 and Ajayi et al., 2012) that aid reduction of water loss (Ansart et al.,2002 and Omoyahki et al., 2008).

It is appear from our results that the emergence of the aestivated snails is strongly influenced by the changes of temperature (aestivated snails were more active at temperature $25{ }^{\circ} \mathrm{C}$ and became less active with increasing temperature), that trigger the genetic process and induce aestivation in snails (Rahman and Raut, 2010).This finding is in accordance with that obtained by Ali and Suleman,( 1992) who assured that in Pakistan both the adult and immature stages snails of M.obstructa were more active during wet days of spring months where the prevailing temperatures were around $25^{\circ} \mathrm{C}$ and become inactive during the summer months and they either died or aestivated, as large numbers of empty shells and dormant snails were observed.

Tolerance to high temperature levels, 30- 35 and $40{ }^{0} \mathrm{C}$ supported finding by many authors. Riddle (1983) reported that the most stylommatophora snails are able to aestivate over periods of unfavorable conditions, with the retracted gastropod into the shell and the shell aperture sealed with one or more epiphragm. Raut and Ghose (1984) found that Achatina Fulica adapt well to temperature range of $0-45{ }^{\circ} \mathrm{C}$, but for population built up at temperature range of $22-32^{\circ} \mathrm{C}$ is required. Kempster and Charwat (2003) indicated that the adult snails of Theba pisana were incapable of surviving when incubated at $55{ }^{\circ} \mathrm{C}$, and died after $3 \mathrm{hrs}$ while Cernuella virgata and Cochlicella acuta survived longer, with $100 \%$ mortality only after two successive 6 hrs exposure at $55^{\circ} \mathrm{C}$.

Generally, knowledge of the activity of the aestivated snails and its ability to tolerate elevated temperature levels in turn can be used both for predicting snail diversity and abundance in new unsurveyed areas and for projecting the effectiveness of control programmes. 
Table 4. (groups1,2,3,4,5): Effect of different temperature degrees on the emergence of aestivated $M$. cartusiana snails during five days period.

Group (1)

\begin{tabular}{|c|c|c|c|c|c|c|c|}
\hline \multirow{2}{*}{$\begin{array}{l}\text { Temp. } \\
\text { degree }\end{array}$} & \multirow{2}{*}{$\begin{array}{l}\text { No.of } \\
\text { snails }\end{array}$} & \multicolumn{5}{|c|}{ \%Emerged snails after indicated days } & \multirow{2}{*}{ Total mean } \\
\hline & & 1 & 2 & 3 & 4 & 5 & \\
\hline 10 & 50 & 0 & 4 & 4 & 2 & 6 & 3.2 \\
\hline 15 & 50 & 4 & 4 & 6 & 6 & 8 & 5.6 \\
\hline 20 & 50 & 4 & 10 & 14 & 16 & 16 & 12 \\
\hline 25 & 50 & 18 & 20 & 20 & 18 & 20 & 19.2 \\
\hline 30 & 50 & 18 & 18 & 18 & 20 & 14 & 17.6 \\
\hline 35 & 50 & 14 & 14 & 10 & 10 & 10 & 11.6 \\
\hline 40 & 50 & 2 & 0 & 0 & 0 & 0 & 0.4 \\
\hline
\end{tabular}

Group (2)

\begin{tabular}{|c|c|c|c|c|c|c|c|}
\hline \multirow{2}{*}{$\begin{array}{l}\text { Temp. } \\
\text { degree }\end{array}$} & \multirow{2}{*}{$\begin{array}{l}\text { No.of } \\
\text { snails }\end{array}$} & \multicolumn{5}{|c|}{ \%Emerged snails after indicated days } & \multirow{2}{*}{ Total mean } \\
\hline & & 1 & 2 & 3 & 4 & 5 & \\
\hline 15 & 50 & 0 & 14 & 16 & 16 & 18 & 12.8 \\
\hline 20 & 50 & 20 & 34 & 34 & 36 & 42 & 33.2 \\
\hline 25 & 50 & 52 & 54 & 48 & 48 & 48 & 50 \\
\hline 30 & 50 & 46 & 44 & 42 & 40 & 24 & 39.2 \\
\hline 35 & 50 & 36 & 36 & 36 & 32 & 30 & 34 \\
\hline 40 & 50 & 14 & 12 & 6 & 0 & 0 & 6.4 \\
\hline
\end{tabular}

\begin{tabular}{lccccccc}
\multicolumn{7}{c}{ Group(3) } \\
\hline Temp. & No.of & \multicolumn{7}{c}{ \%Emerged snails after indicated days } & \multirow{2}{*}{ Total mean } \\
\cline { 2 - 7 } degree & snails & $\mathbf{1}$ & $\mathbf{2}$ & $\mathbf{3}$ & $\mathbf{4}$ & $\mathbf{5}$ & 8.8 \\
20 & 50 & 4 & 6 & 10 & 12 & 12 & 17.2 \\
25 & 50 & 16 & 18 & 16 & 18 & 18 & 16 \\
30 & 50 & 16 & 16 & 16 & 16 & 16 & 15.2 \\
35 & 50 & 16 & 16 & 16 & 14 & 14 & 7.6 \\
40 & 50 & 12 & 12 & 14 & 0 & 0 & \\
\hline
\end{tabular}

Group (4)

\begin{tabular}{lccccccc}
\hline Temp. & No.of & \multicolumn{9}{c}{ \%Emerged snails after indicated days } & \multirow{2}{*}{ Total mean } \\
\cline { 2 - 7 } degree & snails & $\mathbf{1}$ & $\mathbf{2}$ & $\mathbf{3}$ & $\mathbf{4}$ & $\mathbf{5}$ & 3.6 \\
25 & 50 & 4 & 2 & 4 & 4 & 4 & 2 \\
30 & 50 & 2 & 2 & 2 & 2 & 2 & 2 \\
35 & 50 & 2 & 2 & 2 & 2 & 2 & 5.6 \\
40 & 50 & 4 & 6 & 6 & 6 & 6 & \\
\hline
\end{tabular}

Group (5)

\begin{tabular}{lccccccc}
\hline Temp. & No.of & \multicolumn{9}{c}{ \%Emerged snails after indicated days } & \multirow{2}{*}{ Total mean } \\
\cline { 3 - 8 } degree & snails & $\mathbf{1}$ & $\mathbf{2}$ & $\mathbf{3}$ & $\mathbf{4}$ & $\mathbf{5}$ & 5.6 \\
30 & 50 & 4 & 8 & 6 & 6 & 4 & 4 \\
35 & 50 & 4 & 4 & 4 & 4 & 4 & 4 \\
40 & 50 & 4 & 4 & 0 & 4 & 8 & 4 \\
\hline
\end{tabular}

\section{REFERENCES}

Abed. M.A.M.,(2017).Apllication of some integrated control methods on some land snail species in Sharkia Governorate. Ph. D. Thesis, Fac. Science,Al-Azhar Univ. 140 pp.

Abd El-Aal, E.M., (2007). Ecological, biological and control studies on certain land snail species in Sharkia Governorate. Ph. D. Thesis, Fac. Agric., Zagaizg Univ. 185 pp.

Ackefors, H.; Huner, J. V., and Konikoff, M. (1994). Introduction to the general principles of aquaculture, Ph. D. Thesis, Food products Press.Inc New York. London Norwood (Australia), 172 pp.
Ajayi, O.A.; Fawole, J.K.; Idowu, A.B. and Ademolu, K.O.(2012). Dynamics of nutrient in the tissues of giant African land snail (Archachatina marginata) during aestivation. Proc.1st Inter. Conf. on Giant African Land Snails. Feb. 2012 Abeokuta, Nigeria : 67-71.

Akinnusi, O. (2014). Snail production and management. Tolukoya publishing company, Abeokuta, Nigeria, $105 \mathrm{p}$.

Al-Akra, T.M.M.(2001). Ecological, biological and toxicological studies on some mollusca species at Monofia and Gharbia Governorate. M. Sc. Thesis, Fac. Agric.,Al-Azhar Univ.,186pp. 
Ali, N. and Suleman, M.(1992). Seasonal variation in population density and activity of the land snail, Monacha obstructa at Peshawar Univ. Campus Pakistan J. Zool., 24(1):85-88.

Ansart, A., Vernon P. and Daguzan J.(2002). Elements of cold hardiness in a littoral population of the land snail Helix aspersa (Gastropoda: Pulmonata). Journal of Comparative Physiology 172: 619-625.

Baur, B.(1990).Possible benfits of egg cannibalism in the land snail Arianta arbustorum (L.). Functional Ecol. 4(5): 679-684.

Baur, B., and Baur A.(1993). Climatic warming due to thermal radiation from an urban as possible cause for the local extinction of a land snail .J. Appl. Ecol., 30: 333 - 340.

Calve, D. L.(1989). Influence of incubation conditions of eggs on the first six weeks of growth of snails, Helix aspersa Muller (Gastropoda, Pulmonata, Stylommatophora). Bulletin de la Societe Zool. De France, 114 (1): 101-110.

Cook, A.(2001). Behavioural Ecology: On doing the right thing, in the right place at the right time. In Barker, G.M. (Ed.), The biology of terrestrial molluses Wallingford (U.K.): CAB International, pp. 447-487.

El-Massry, S. A. A.(1997). Studies on the control of some land snails infesting certain fruit trees. $\mathrm{Ph}$. D. Thesis, Fac. Agric., Zagazig Univ., 150 pp.

El-Okda, M. M. K. (1981). Response of two land mollusca to certain insecticides. Bull. Ent. Soc. Egypt. Econ. Ser., 12, 53-57.

Godan, D. (1983). Pest slugs and snails, biology and control. Springer-Verlag Berlin, Heidelberg. 445 pp.

Kempster, V., and Charwat, S.(2003). Soil surface temperature and mortality in land snails: implications for successful management. Australian J .Exper. Agric 43(11):1351-1356.

Kingsolver, J.G. and Huey, R.B.( 2008). Size, temperature, and fitness: three rules. Evol. Ecol. Res. 10: 251-268.

Lokma, M. H. E.(2007). Studies on some terrestrial gastropods injurious to field crops at Sharkia Governorate. M.Sc. Thesis, Fac. Agric., Zagazig Univ. 147 pp.

Lokma, M. H. E.(2013). Studies on some terrestrial gastropods injurious to vegetables and field crops in the East Delta locality (Sharkia and Ismailia). $\mathrm{Ph}$. D. Thesis, Fac. Agric., Zagazig Univ. 161 pp.

Mahrous, M. E.; Ibrahim Mervat, H. and Abd El- Aal, E. M.(2002). Ecobiological aspects of the glassy clover snail, Monacha cartusiana (Muller) under field conditions in Sharkia Governorate, Egypt. Proc. $2^{\text {nd }}$ Inter. Conf. Plant, Prot. Res. Instit. Cairo, Egypt: 1:107-114.

Mahrous, M. E.; Basha, A.E.; Ibrahim Mervat, H.; Ismail A.A. and Lokma, M. H. (2006). Observation on aestivation, dispersal and breeding season of the glassy clover snail, Monacha cartusiana (Muller) at Sharkia Governorate, J. Agric. Sci. Mansoura Univ.31(8).5487-5497.
Martin, K.and Sommer, M. (2004). Relationships between land snail assemblages patterns and soil properties in temperate-humid forest ecosystems. J. Biogeogr 31:531-545 .

Metwally, A.M.; Zedan,H.A.; El-Saeid, A.B.and AlAkra, T.M.M.(2002). Ecological studies on certain land snails in Monofia and Gharbia Governorate. Proc. $2^{\text {nd }}$ Inter. Conf. Plant, Prot. Res. Instit. Cairo, Egypt: 65-79.

Millar, A.J.and Waite, S.(2002). The relationship between snails, soil factors and calcitic earthworm granules in a coppice woodland in Sussex. Journal of Conchology, 37( 5) : 483503.

Mohamed-Ghada, R.Y.(2004). Ecological and biological studies on some species of snails. M.Sc. Thesis in Agric., Mosh. Zagazig Univ. 204.pp.

Mohamed, M.F.M.(1999). Ecological and biological studies on land snails and slugs in Egypt. Ph.D. Thesis, Faculty Agric., Cairo, Univ. 170 pp.

MSTAT.Version4(1987).Software program for the design and analysis of agronomic research experiments.Michigan ST.Univ.U.S.A.

Nakhla, J. M.; Rizk, M.A. and, Tadros, A.W. (1995). Host preference of land snails as indicated by plant cells in their excrement. Egypt J. Agric., Res. 73 (1): $95-109$.

Omoyakhi J.M., Osinowo O.A. ;Onadeko S.A. and Ozoje M.O. (2008). Adaptive changes in growth and morphological composition of aestivating giant African land snails, Achatchatina marginata and Achatina achatina. African Journal of General Agriculture, 4(4): 241-249.

Osunkeye, O. J.; Osinowo, O. A.; Idowu, A. B. and Adenowo, J. A.( 2006). Effects of temperature and moisture on the cumulative and weekly weight gain of giant African land snails (Archachatina marginata and Achatina achatina).University of Agriculture, Abeokuta, Nigeria, ASSET - Series A: Agriculture and Environment, , 6( 2): 37-44.

Panigrahi, A. and Raut, S. K.(1994). Levels of noradrenaline and adrenaline in the cerebral ganglia of the land snail Achatina fulica Bowdich in respect to aestivation. Moll. Res., 15:39-41.

Rahman, M.S. and Raut, S. K.(2010). Factors inducing aestivation of the giant African land snail Achatina fulica Bowdich (Gastropoda : Achatinidae). Proc. Zool. Soc. 63 (1) : 45-52.

Ramzy, R.R.(2009). Biological and ecological studies on land snails at Assiut, Egypt. M. Sc. Thesis, Faculty of Science, Assiut University, Egypt, $164 \mathrm{pp}$.

Rangarajan, R. and Ghosh, P.(2013). Seasonal variability of rainfall recorded in growth bands of the giant African land snail Lissachatina fulica (Bowdich) from India. J. Chemical Geology. 357, 223-230.

Raut, S. K. and Ghose, K. C.(1984). Pestiferous land snails of India. Technical Monograph, No.11. Zoological Survey of India, Calcuta. 151 pp. 
Riddle, W. A. (1983). Physiological ecology of land snails and slugs. In: Russel-Hunter, W.D. and Wilbar, K.M. (eds). The mollusca Vol. 6, Ecology Academic Press, New York, pp. 431461.

Shahawy, W.A.; Hendawy, E.; Abada, A.S.A.and Kassem, A.A.( 2008). Land snails infesting rice plants and their accompanied parasitoids and predators at Kafr El-Sheikh Governorate, Egypt. Egyptian J. Agric. Res. 86: 971-980.
Storey, K.B. (2002). Life in the slow lane: molecular mechanisms of aestivation. Comparative Biochemistry and Physiology, Series A, 133: 733-754.

Waldbaner, G.P.(1964). The consumption, digestion and utilization of solanaceous and non- solanaceous plants by larvae of the tobaccoo hornworm, Procoparce sexta (Johan) (Lep. Sphingidae). Ent. Exp. and Appl. 7: 253-269.

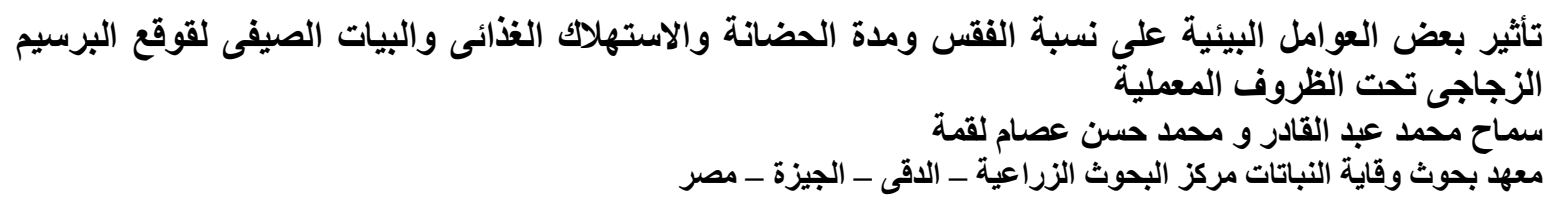

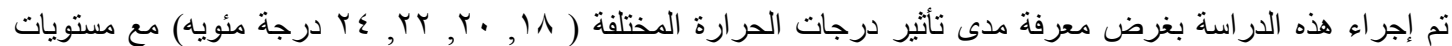

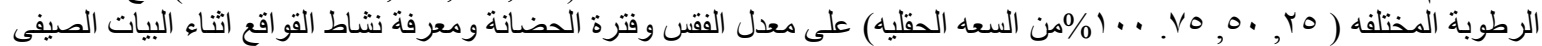

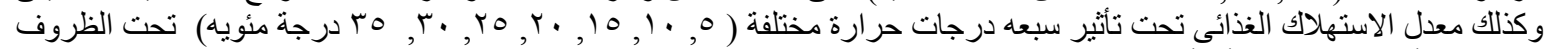

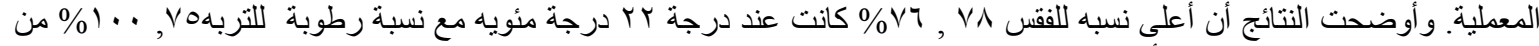

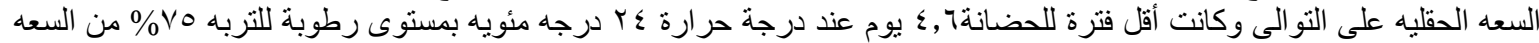

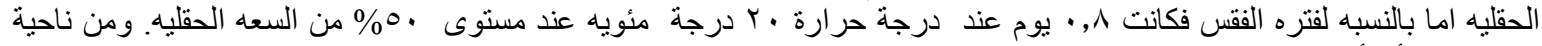

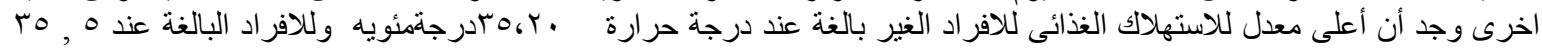

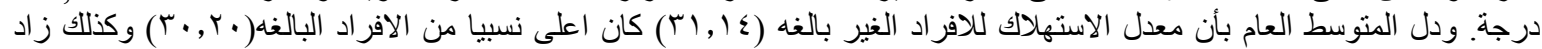

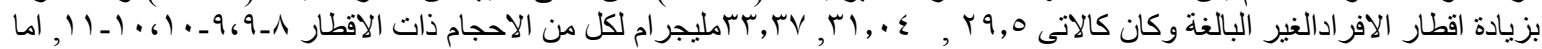

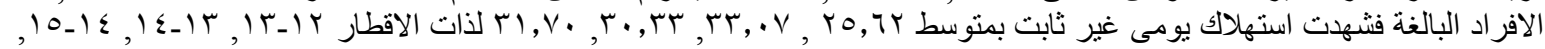

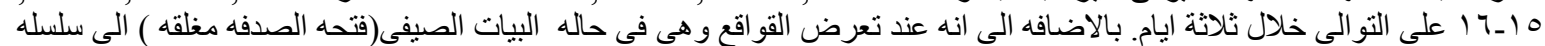

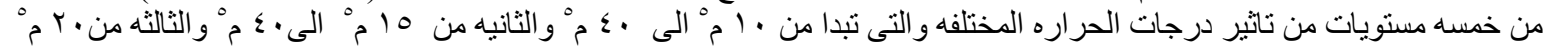

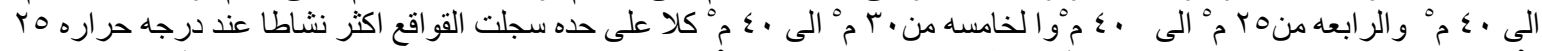

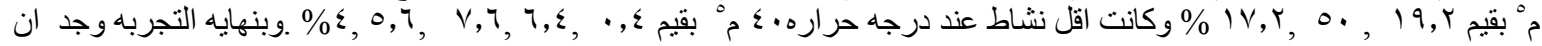

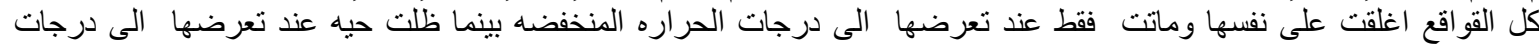
الحراره المرتفعه. 